\title{
吸い込み・吹き出し速度の armor coat 形成に及ぼす影響 Effect of Suction or Injection through Bottom on Armor Coat Formation
}

$\begin{array}{llll}\text { 京都大学工学部 } & \text { 中川 } & \text { 博次 } & \text { H. Nakagawa } \\ \text { 金沢大学工学郎 } & \text { 辻本 } & \text { 哲郎 } & \text { T. Tsujimoto } \\ \text { 京都大学工学部 } & \text { 村上 } & \text { 正吾 } & \text { S. Murakami } \\ \text { 京都大学工学部 } & \text { 清水 } & \text { 義彦 } & \text { Y. Shimizu }\end{array}$

\section{1. まえがき}

砂床河川の河床は，一般に広い粒度分布を有し，その高い透水性のため，河床表首に誘起される浸透流の 存在は無視し得ず，流砂現象に種々の影響を及ぼしているものと推測される。例えば，混合砂の場合，粒径 によって流送特性が異なるため, 必然的に非平衡状態が出現し, 結果としていわゆる分級現象が顕著となっ てくる。一方, 透水性河床内の浸透流の存在は, 河床境界面を通しての, 浸透流と表面流との間の活発な質 量・運動量交換の存在を意味しており, これが, 表面流の構造を変化させるとともに, 流砂現象の変化をも 産む。こうした影響は，粒径によって相当大きく異なることが予想され，結果として，粒径別選択輸送の継 続による河床粒度構成の変化過程, armor coat の形成・伝播過程に顕著な変化を産むことが考えられる。 ところで，浸透流と表面流の著しい相互作用を代表する境界面を通しての変動する transpiration（流出入） 速度そのものの検討は容易ではなく，ここでは，比較的取り扱いが容易な定常な transpiration（suction あ るいは injection)の存在を考え, これによる表面流の構造の変化, また混合砂喽床を構成する各粒径の粒子 の流送への直接的・間接的な影響を検討し，代表的な分級現象である armoring への効果を明らかにする。 こうした定常な transpiration の流砂現象への影響を明らかにすることは，より一般的な透水性河床での流砂 現象を考える上で重要な役割を果たすものと考えられる。

\section{2. 流出入流速の混合砂床上の開水路流れに及ぼす影響}

混合砂啋の流送は, 河床表面の粒度構成に影響されるとともに, 流送によって河床粒度構成そのものも変 化する複雑な現象であり, その合理的記述のためには, 砂粒の運動特性を粒径別に明らかにすることが重要 である。また, その本質的な非平衡性を考虑すると, pick-up rate と step lengthより構成される stochastic model の適用が適切と考えられる。これらのことより, 初期移動掞よび流送過程の代表特性量である pick-up rate, step lengthの粒径別の特性を, 力学的合理性に留意して評価する必要がある。そのためには, 砂粒に 作用する流体力を適切に評価することが重要で, 先ず, transpiration 速度の存在する混合砂礫床上の流れの 流速分布の検討を進める。著者らは，すでに transpiration 速度 $v_{0}$ （吹き出しを正とする）の存在する粗面 河床上の流れに対するいわゆる対数 2 乗則を誘導しておりり, 次式で表わされる。

$$
U^{+} \equiv \frac{U}{u_{*}}=\frac{v_{0}^{+}}{4 \kappa_{0}^{2}}\left(\ln \frac{y}{k_{s}}\right)^{2}+\frac{1}{\kappa_{0}}\left(\frac{v_{0}^{+}}{2} D_{r}+1\right) \ln \frac{y}{k_{s}}+\left(\frac{v_{0}^{+}}{4} D_{r}+1\right) D_{r}
$$

但し, $U$ : 表面流の流速, $u_{*}$ : 摩擦速度, $v_{0}^{+} \equiv v_{0} / u_{*}, \kappa_{0}$ : カルマン定数, $D_{r}=\left(1 / \kappa_{0}\right) \iota n\left(y_{0} / k_{s}\right), y_{0}: v_{0}=0$ の場合, 対数則を適用して流速が 0 となる高さ， $k_{s}$ : 等価砂粗度である。式(1)の適用性は, 一様砂啋床上の流 れに対しては, 実験的に確かめられている。立ところで, 混合砂磻床上の流れの場合は, 等価砂粗度 $k_{s}$ の評価 が重要であるにも関わらず, transpiration 速度がない場合においてさえ， $k_{s}$ として経験的に平均粒径 $d_{m}$, $65 \%$ 粒径 $d_{65}$ や, 他の粒径が用いられるが，その物理的意味は明確でない。ここでは, transpiration 速度が存在 する混合砂磷上の流れに対する等価砂粗度の合理的な評価を行うため, 既に著者らによって提案されている「相 当径」（equivalent size）の概念を適用する。文すなわち, transpiration 速度の存在する混合砂礫床上の流速 分布によって代表される流れの特性が，ある均一粒子径 $d_{e}$ より成る河床上のそれと等価である時，2つの 
河床での単位面積当りの掃流力は同一であるはずであり，従って次式が成立する。

$$
\varepsilon_{0} C_{D 0} \frac{1}{2} \rho u_{b_{0}}^{2} A_{2} d_{e}^{2} \frac{1}{A_{2} d_{e}^{2}}=\sum \varepsilon_{0 i} C_{D_{0 i}} \frac{1}{2} \rho u_{b_{i}}^{2} A_{2} d_{i}^{2} \frac{p_{i}}{A_{2} d_{i}^{2}}
$$

ここに, $\varepsilon$ : 遮蔽係数, $C_{D}$ : 抗力倸数, $\rho$ : 流体の密度, $u_{b}$ : 砂粒近傍の局所流速, $A_{2}$ : 砂粒の 2 次元形状 倸数, $p_{i}$ : 粒径 $d_{i}$ の砂の体積の全体積に対する割合, 添字 0 は均一砂, 添字 $i$ は粒径 $d_{i}$ の粒度クラス $i$ の砂 に対する諸量をそれぞれ示す。簡単のため, 各粒径について $\varepsilon_{0 i}, C_{D 0 i}$ が共通で, 均一砂のそれに等しいと仮定 する。また, 粗度特性が同一であることより, 両河床の上での流速分布は同一であり, transpiration 速度の 存在する粗面乱流に対する 2 乗対数則が適用されるものとすると, 式(2) は次のように書き直せる。

$$
\left[A_{0}\left\{\ln \frac{a}{\alpha}\right\}^{2}+B_{0} \ln \frac{a}{\alpha}+C_{0}\right]^{2}=\int_{\eta_{c}}^{\infty}\left[A_{0}\left\{\ln \frac{a \eta}{\alpha \eta_{e}}\right\}^{2}+B_{0} \ln \frac{a \eta}{\alpha \eta_{e}}+C_{0}\right]^{2} p(\eta) d \eta
$$

但し，

$$
\begin{aligned}
& A_{0}=v_{0}^{+} / 4 \kappa_{0}^{2}, \quad B_{0}=\left(v_{0}^{+} D_{r} / 2+1\right) / \kappa_{0}, \quad C_{0}=\left(v_{0}^{+} D_{r} / 4+1\right) D_{r} \\
& \eta=d / d_{50}, \quad \eta_{e}=d_{e} / d_{50}, \quad \eta_{c}=\alpha \eta_{e} / 30.1 a
\end{aligned}
$$

であり, $d_{50}$ : 混合砂の中央粒径, $a$ : 混合砂磁床における流速分布 の理論的河床面からの砂粒中心の無次元高さ $\left(a \equiv y_{i} / d_{i} \cong 0.5\right.$ が ほぼ認められる $), \alpha=k_{s} / d(\alpha=1 \sim 3), p(\eta)$ : 粒度分布の密 度関数である。なお, 式(3) では, $d<\left(k_{s} / 30.1 a\right)$ の小粒径の砂に対 しては抗力が作用しないものとしている。式(3)より, ln $\eta_{e}$ について の 4 次の方程式が得られる。ここでは, 実河川の河床材料の粒度構 成を良く表示すると言われる対数正規分布型の粒度分布を対象とし， さらに, $\alpha=1\left(k_{s}=d_{e}\right.$, よって $\left.\eta_{e}=k_{s} / d_{50}\right)$ とした時の, 式(3)の解 $\eta_{e}$ の粒度分布の幾何学的標準偏差 $\sigma_{g}\left(\equiv \sqrt{d_{84} / d_{16}}\right)$ に対する変化を, v゚をパラメータにして示した。図より, transpiration 速度が存在す る混合砂磁床上の流れに対する等価砂粗度は, 無い場合のそれを援

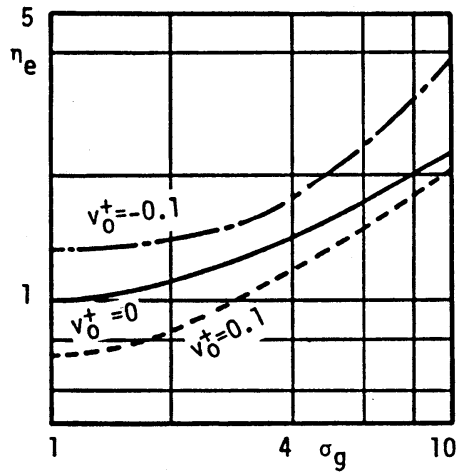

図一 1 等価砂粗度の評価 用し難いことが知れる。また，吹き出しの場合は，無い場合よりも，等価砂粗度が小さくなる傾向にあり，吸 込みの場合は逆の傾向を呈するとともに，その効果は，吹き出しょり大きいことも理解される。次に， transpirationの混合砂磷床上の流れの抵抗に及ぼす影響についての検討を行う。ここでは，その効果を示す 指標として, $\Omega \equiv U_{m n} / U_{m}$ を導入する。但し, $U_{m}$ は平均流速であり, 添字 $n$ は, transpiration が無くて, 同一の表面流流量とェネルギー勾配を有する流れに対する諸量を示す。また，この時， $\Omega$ につては， $\Omega=h / h_{n}=\sqrt[3]{f / f_{n}}$ と表わすことも可能である。ここに, $h:$ 水深, $f:$ 抵 抗係数である。式(1)を水梁に亘って積分し，transpirationのある場合とない場 合の比較を行うことにより，流水抵坑に及ぼす transpiration の効果を表わす 次式を得る。

$$
\begin{aligned}
\frac{v_{0}^{+}}{4}\left\{\frac{2}{f_{n}}\right. & \left.+\frac{(\ln \Omega)^{2}+1}{\kappa_{0}}\right\}+\frac{\ln \Omega}{\kappa_{0}}\left(1+\frac{v_{0}^{+}}{2 \kappa_{0}} \ln \frac{k_{s n}}{k_{s}}\right)+\frac{1}{\kappa_{0}} \ln \frac{k_{s n}}{k_{s}}\left(1+\frac{v_{0}^{+}}{4 \kappa_{0}} \ln \frac{k_{s n}}{k_{s}}\right) \\
& =\sqrt{\frac{2}{f_{n}}}\left[\Omega^{-\frac{3}{2}}-\frac{v_{0}^{+}}{2 \kappa_{0}}\left(\ln \Omega+\ln \frac{k_{s n}}{k_{s}}\right)-1\right]
\end{aligned}
$$

均一砂の場合と異なり, 上式には, transpirationの存在によって, 等価砂粗度 が変化することによる付加項が加わる。図一 2 は, $f_{n}=$ const. として, $\sigma_{g}$ をパ ラメータとして $\Omega \sim v_{0}^{+}$関係を示したものである。但し, $k_{s n} / k_{s}=d_{e n} / d_{e}$ と見 なし，式(3)上り評価を行った。図より，混合砂碰床においても，吹き出しによ る抵抗減, 吸い込みによる抵抗増が認められる。

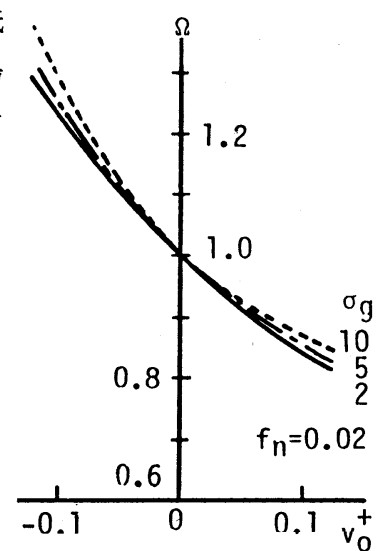

図一 $2 v_{0}^{+}$による抵抗変化 


\section{3. 流出入流速の混合砂碟の粒径別運動特性に及ぼす影響}

混合砂磷の流送に強い影響を与える粒径による移動限界の相違は, 各粒径毎の平均的な存在高さ及び河床 面からの抜け出し角の相違と，混合砂碰床の等価砂粗度に支配されている。著者らは，すでに，これらの要 素のうち, 平均存在高さと $v_{0}=0$ の場合の等価砂粗度 $k_{s n}$ を取り込んだ形で, transpirationの存在する場合の 粒径別無次元限界掃流力 $\tau_{*_{c i}}$ 及び無次元粒径別 pick-up rate $p_{s * i}$ を定式化しているが, ${ }^{3)}$ 本研究では, 式(3), (6) にもとづいて, transpirationの存在による $k_{s}$ の変化を取り込むことを意図しており，次式で表わされる。

$$
\begin{aligned}
& p_{s * i} \equiv p_{s i} \sqrt{\frac{d_{i}}{(\sigma / \rho-1) g}}=F_{0} \frac{\tau_{* c n 0}}{\tau_{* c n i}} \frac{1}{\Psi_{i}} \tau_{* i}\left(1-\frac{k_{2} \Psi_{i} \tau_{* c n i}}{\tau_{* i}}\right)^{n} \\
& \tau_{* c i} / \tau_{* c 0}=\left(\Psi_{i} / \Psi\right) \cdot\left(\tau_{* c n 0} / \tau_{* c n i}\right) \\
& \Psi_{i}=\Omega\left(1+k_{2} \mu_{f}\right) /\left[\widetilde{\phi}_{0 i}^{2}\left\{1+\left(k_{L}+\phi_{1 i}\right) \mu_{f}\right\}\right], \tau_{* i}=u_{*}^{2} /\left\{(\sigma / \rho-1) g d_{i}\right\} \\
& \widetilde{\phi}_{0 i}=U_{d i}^{+} / U_{d n i}^{+} ; \quad \phi_{1 i}=\left(\varepsilon_{0 i}^{\prime} C_{D i}^{\prime} / \varepsilon_{0 i} C_{D i}\right)\left|v_{0}^{+}\right| v_{0}^{+} / U_{d}^{+2}
\end{aligned}
$$

ここで, $F_{0}, k_{2}, n$ の定数については, 不浸透性平坦河床 での值を援用する。また, $k_{L}$ : 揚力と抗力の比, $\mu_{f}$ : 砂 の静止摩擦係数, $\varepsilon_{0 i}^{\prime} C_{D 0 i}^{\prime}: v_{0}$ に対する遮蔽倸数, 抗力 係数, $U_{d}$ : 河床砂砂近傍の局所流速, 上付添字十は $u_{*}$ で 無次元化したことを，下付添字 $n$ は transpirationがない 場合の值を，0 は均一砂に対する值を示す。ところで, 式(8)の中の $\left(\tau_{* c n i} / \tau_{* c n 0}\right)$ は, 粗面対数則を適用し, 式 (3)を考慮すると次式で表わされる。

$$
\frac{\tau_{* c n i}}{\tau_{* c n 0}}=\left[\frac{\ln (30.1 a)}{\ln \left\{30.1 a\left(\eta_{m n} / \eta_{e n}\right) \zeta_{i}\right\}}\right]^{2} \ldots \ldots \ldots
$$

ここに, $\eta_{m} \equiv d_{m} / d_{50}, \zeta_{i} \equiv d_{i} / d_{m}, d_{m}$ : 平均粒径である。 なお, 芦田・道上 ${ }^{4)}$ は $\zeta_{i} \leqq(1 / 30.1 a)$ の場合には, 式(11) は適用し難いことから，次のような修正を行っている。

$$
\tau_{* c n i} / \tau_{* c n 0}=0.85 / \zeta_{i}\left(\zeta_{i} \leqq 0.4\right)
$$

本研究においても，小粒径のものに対しては，式(12)を用 いる。図ー 3 は, transpiration の存在による等価砂粗度 の変化を考慮して, 式(8), (12)にもとづいて粒径別無次元 限界掃流力の混合砂の平均粒径に等しい均一砂のそれに 対する比 $\left(\tau_{* c i} / \tau_{* c 0}\right)$ を示したものである。一方, 図 - 4 は, 粒径別無次元限界掃流力と均一砂のそれとの比 が, transpirationの存在によってどのように変化するか を示したもので，両図より，吹き出しに対しては細粒分 の運動が抑制され，粗粒分の運動は促進される。一方, 吸い込みに対しては逆の様相である。困一 5 は, 式(7)に もとづいて, 粒径別無次元底面せん断応力 $\tau_{* i}$ と無次元 粒径別 pick-up rateの関係を示したものである。なお, 計算に当っては, 混合砂の粒度分布は対数正規分布に従 うものとした。

一方, step length は一般的に幾つかの不規則継続跳躍 より構成されているが, 床面との確率的な衝突・反発過 程を充分に考慮した上で，力学的な定式化を行うことは

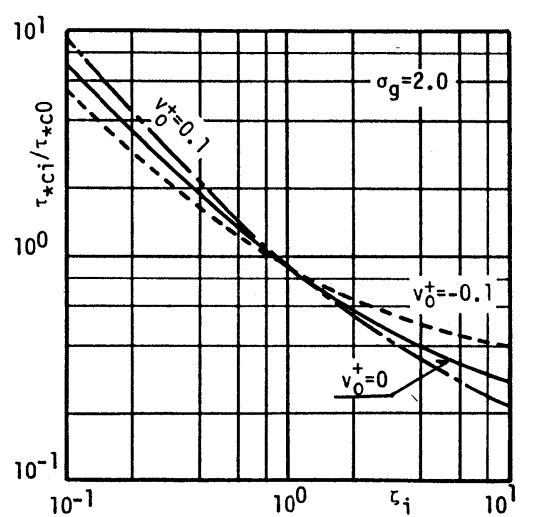

図一 3 粒径別無次元限界掃流力

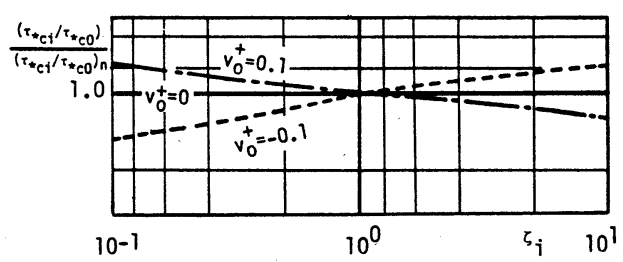

図-4 $\left\{\left(\tau_{*_{c} i} / \tau_{* c 0}\right) /\left(\tau_{* c i} / \tau_{*_{c} 0}\right)_{n}\right\}$ と $\zeta_{i}$ の関係

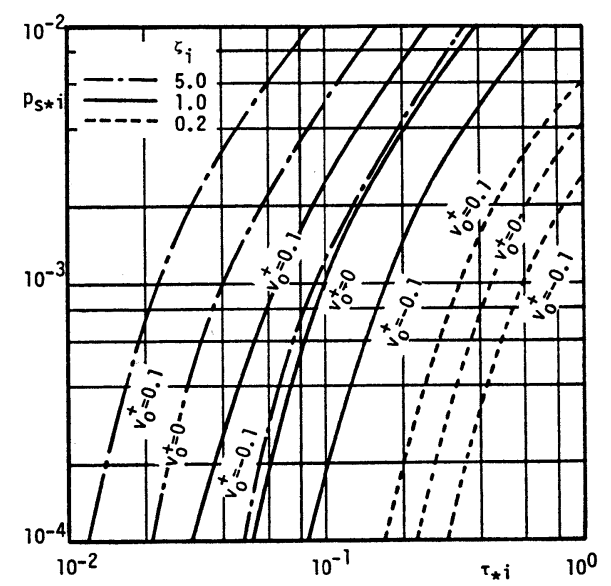

図-5 粒径別無次元 pick-up rate 
容易ではなく,トレーサ実験と併行した検討が必要である。均一砂の step length に及ぼす transpiration の 効果は, 著者らにより検討されており, transpiration の存在によって, 平均值は変化し, 特に, 限界掃流力 付近では吸い込みで増加，吹き出しで減少することが理論的・実験的に明らかにされている。 また，その分 布は，transpirationの有無に関わらず指数分布であることも見い出されており，後述する粒径別 step length に関する実験においても，平均值自体は小さくなるものの，均一砂の場合と同様の傾向が見出されている。 従って, 均一砂の場合と同様に, その粒径別平均值及び確率密度関数をそれぞれ

$$
\Lambda_{i}=\lambda_{i}\left(v_{0}^{+}\right) \cdot d_{i} \quad f_{X_{i}}(\xi)=\left(1 / \Lambda_{i}\right) \exp \left(-\xi / \Lambda_{i}\right)
$$

と仮定しても差支えないものと考えられる。均一砂の場合には, step lenth を支配する要素が, 河床面との 衝突・反発事象と, こうした事象間での加速過程であることに着目し, それぞれに対する transpirationの効 果を抽出し，入と $v_{0}^{+}$との関係が得られたが，混合砂磁床においては，粒度分布の衝突・反発事象に関倸する 砂粒の凸凹状況への効果を明らかにすることは難しく， $\lambda_{i}$ と $v_{0}^{+}$の関係は実験的に定めなければならない。

粒径別の pick-up rateの推定式(7) 及び式(8) (12)，さらに粒径別 step length に関する式(13)によって, 初

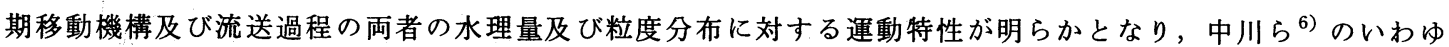
る parallel degradation の場合の armor coat の形成・伝播過程に対するモデルに組み入れることにより， 混合砂磷床の粗粒化過程に及ぼす transpiration の影響の検討が可能となる。

\section{4. 流出入流速の混合砂喽の粒径別運動特性に及ぼす影響に関する実験}

実験は, 図一 6 に示すような長さ $8 \mathrm{~m}$, 幅 $33 \mathrm{~cm}$ の鋼製可変勾配水路で, 図一 7 に粒径加積曲線を示す混 合砂を用いて行った。実験水路中, pick-up rate 測定用実験に対しては約 $50 \mathrm{~cm}$, step length 及び粗粒化過 程の実験に際しては約 $1 \mathrm{~m}$ を, 前述の混合砂を河床材料とする移動床区間とし, その上下流は移動床部と同 一の混合砂を用いて固定床粗面とした。

移動床部分底部のバルブを調節すること により，所定の流出入流速を与えること ができるように工夫した。図ー8は，混 合砂磘床上の流速分布をピト一管を用い て測定した例であり，式(1)で示される対 数 2 乗則の成立する領域が認められる。 $k_{s}=(1 \sim 3) d_{50}$ であり,この水理条件に 対して計算される $\left(\eta_{e} / \eta_{e n}\right)$ とほぼ等しく, transpiration の存在する混合砂磷床の流 れに対する等価砂粗度の評価法としての 合理性が認められるものと考える。また, 図一 9 は，吸い込み，吹き出しを行うこ とによる流水抵抗の変化と, その時の $v_{0}^{+}$との関係を示したもので, 式(6)で表 わされる理論曲線と比較的良好な一致を 見せており，transpirationの存在による 等価砂粗度の変化を含めて, 式(6)の適用 性が示された（実験条件表一1参照)。

pick-up rate は, 移動床部上方に設置 されたビデオカメラに撮影された画面よ り, 粒度クラス毎に着色された砂粒の単

\section{表一 1 実験条件表}

\begin{tabular}{|c|c|c|c|c|l|l|c|l|}
\hline Run & $i_{b}$ & $h(\mathrm{~cm})$ & $u_{m}(\mathrm{~cm} / \mathrm{s})$ & $\mathrm{Fr}$ & \multicolumn{1}{|c|}{$\mathrm{Re}$} & $\mathrm{I}_{\mathrm{e}}$ & $u_{\star}(\mathrm{cm} / \mathrm{s})$ & $\mathrm{v}_{0}^{+}$ \\
\hline 1 & $1 / 300$ & 7.60 & 40.95 & 0.47 & $3.11 \times 10^{4}$ & $3.33 \times 10^{-3}$ & 4.70 & 0 \\
2 & & 7.15 & 44.63 & 0.53 & 3.19 & 2.11 & 3.49 & 0.026 \\
3 & & 7.16 & 40.92 & 0.49 & 2.93 & 2.65 & 4.02 & 0.015 \\
4 & & 7.20 & 40.57 & 0.48 & 2.92 & 4.18 & 5.18 & 0.014 \\
5 & & 6.90 & 41.90 & 0.51 & 2.89 & 4.59 & 5.31 & 0.028 \\
\hline 6 & & 7.58 & 43.61 & 0.51 & 3.31 & 3.33 & 4.66 & 0 \\
7 & & 7.50 & 44.08 & 0.51 & 3.31 & 2.42 & 3.96 & 0.019 \\
8 & & 7.55 & 43.99 & 0.51 & 3.32 & 2.74 & 4.16 & 0.012 \\
9 & & 7.60 & 43.42 & 0.50 & 3.30 & 4.23 & 5.32 & -0.013 \\
10 & & 7.60 & 44.96 & 0.53 & 3.30 & 4.76 & 5.66 & -0.021 \\
\hline 11 & & 7.56 & 43.20 & 0.50 & 3.26 & 3.33 & 4.66 & 0 \\
12 & & 7.58 & 42.17 & 0.49 & 3.20 & 4.67 & 5.62 & -0.021 \\
13 & & 7.50 & 44.08 & 0.51 & 3.31 & 2.33 & 3.79 & 0.022 \\
\hline
\end{tabular}

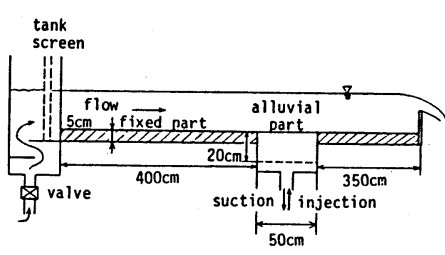

図一 6 実験水路図

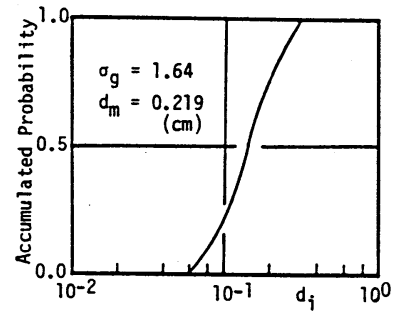

図 - 7 粒径加積曲線 
位面積当りの飛び出し個数を読み取ることによ り求めた。このようにして得られた粒径別無次 元 pick-up rate と, その実験条件に対する理論 引゙ 值との対応を表わしたものが，図一 10 である。 一方, transpiration の粒径別 pick-up rateへの 影響を見るために, transpiration がある場合と ない場合の粒径別 pick-up rateの比 $r \equiv p_{s * i} /$ $p_{s * n i}$ を定義し, $\theta_{0} \equiv \tau_{* 0} / \tau_{* c n 0}$ をパラメータに して, $v_{0}^{+}$と $r$ 関係を示したものが図一11であ る。 $r$ は, 次式で与えられる。

$$
\begin{aligned}
& r=\frac{\Omega}{\Psi_{i}}\left(\frac{\theta_{i}-k_{2} \Psi_{i}}{\theta_{i}-k_{2} \Omega}\right)^{n} \\
& \theta_{i}=\frac{\tau_{* c n 0}}{\tau_{* c n i}} \cdot \frac{1}{d_{i} / d_{m}} \cdot \theta_{0}
\end{aligned}
$$

図一 11 中には, 今回の実験值も併示されている。

条件表-1 中, Run $-6 \sim 10$ がstep length 測 定実験である。各実験とも, 水路側方から目視 により，粒径別に 150 個以上の step length の 標本を得て (直接測定), これょり平均 step lengthのデータを得るとともに，その分布性状 を調べた。また，移動床部下流端に採砂箱を設 け, 流砂量 $q_{B}$ を計測するとともに, 採砂箱上流 の pick-up rateを上方よりのビデオ画像解析に よって求め, 同時に, 混合砂磷床面での粒径 $d_{i}$ の砂の占める面積比率 $p_{i}$ を読み取り, $\lambda_{i}=\left(q_{B * i}\right.$ $\left./ p_{i}\right) \cdot\left(A_{2} / A_{3}\right) \cdot\left(1 / p_{s * i}\right)$ として, 間接的にも 平均 step lengthの算定を行った。図一 12 は, transpirationのない場合とある場合の step lengthの比 $\ddot{\lambda}_{i} / \dot{\lambda}_{i n}$ の $v_{0}^{+}$に対する変化を見たもの で, $d_{i} / d_{m}<1$ の細粒分に対しては，吸い込み が運動を促進, 吹き出しが抑制の効果があり, $d_{i} / d_{m}>1$ の粗粒分汇対しては, 逆の傾向にあ ることが読み取れる。一方, 図ー13 は, 粒径別 step length の変動係数 $\alpha_{x}$ の $v_{0}^{+}$に対する変化 を示したもので, 概小 0.8 程度で, 混合砂の場 合，平均值は transpiration の影響を受けるもの の, 図一 13 及び図一 14 に示される平均值で規 準化された step length の分布図より，その規 準化された統計的構造はほぼ不変であると見な せ, 図ー14より分かるように, ほぼ指数分布で 近似できるものと思われる。

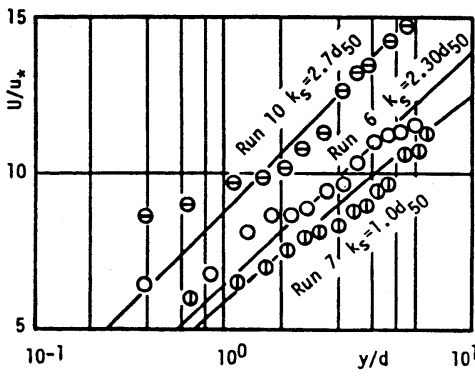

図 -8 流速分布図

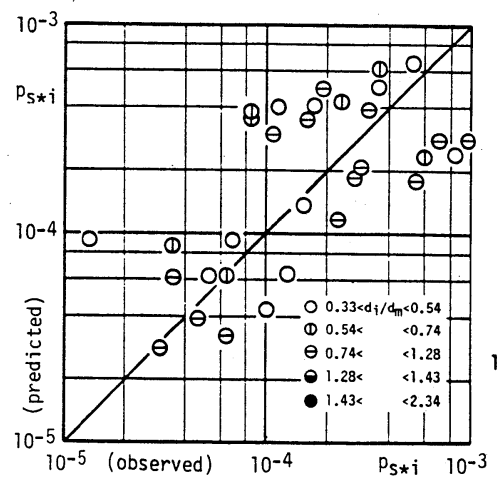

図-10 $p_{s *}$ (理論値と実験值の比較)

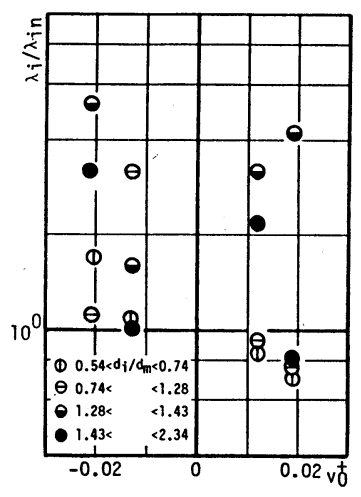

図 $-12 \quad \lambda_{i} / \lambda_{i n} \sim v_{0}^{+}$
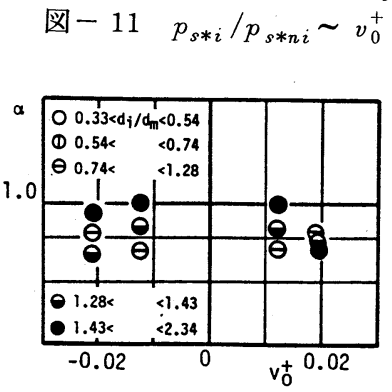

図-13 $\alpha_{x} \sim v_{0}^{+}$

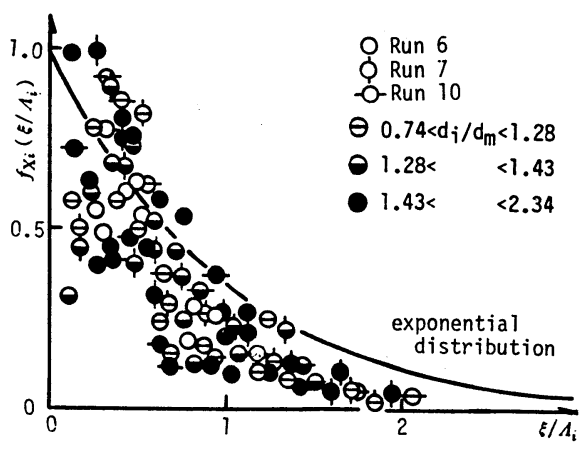

図一 14 規準化された step length の分布 


\section{5. 流出入流速の粗粒化過程に及ぼす影響に関する実験的検討}

実験条件表一 1 の Run - 11 13 に示される水理条件での armor coat の形成及び伝播の特性を調べ，3.に おける考察に基づく数值計算との比較検討を行った。実験における表層の粒度分布の検討は，通水前後におい ては写真撮影により，また通水中は，所定の時刻に，流下方向に亘って上方よりビデオ撮影を行い，それぞ れ，表面露出個数分布をもとに行った。実験によって得られた粗粒化の過程を示したものが，図一 15 (a), (b), (c)であり，図中の実線は，3.で明らかにされた粒径別の砂粒運動特性と armor coat に関する中川らのモデ ルにもとづいて計算された粒度分布である。計算に当っては， $\Delta x$ (水路方向の距離の刻み幅 $)=10 \mathrm{~cm}$, $\mathrm{K}($ 移動床部の分割個数 $)=10, \mathrm{~N}$ (粒度のクラス数 $)=5$ とし, 粒径別の運動特性量は, 3.における考察 と，4. における実験より適宜定めた。なお，時間の刻み幅は， $p_{s i} \Delta t<0.3$ 程度以下におさえた。

得られた数值計算は, 実験結果を良く説明している。

\section{6. あとがき}

本研究では，流出入流速の混合砂の粒径別の運動特性に及ぼす効果の差異に着目し，それらの続続的な選 択輸送によって生じる armor coatの形成・伝播の過程を明らかにするとともに，実験により，モデルの妥当 性を明確にした。今後は，さらに実験值の収集に努めたい。

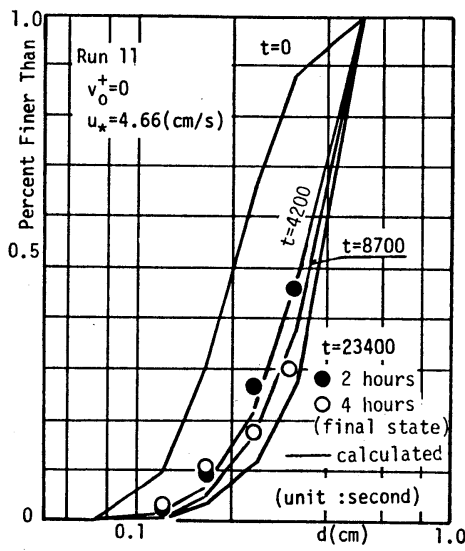

(a)

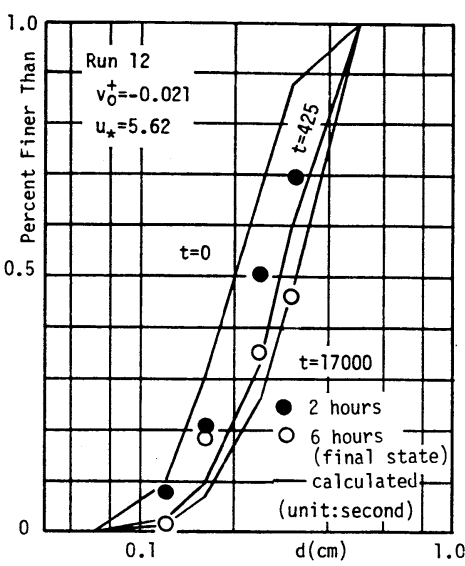

(b)

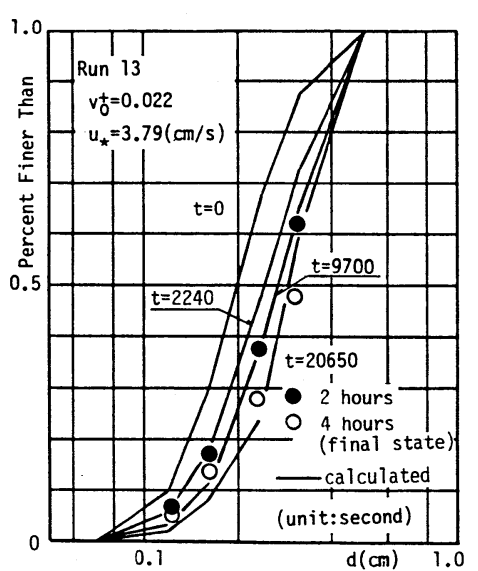

(c)

図-15 armor coat の粒度分布と理論結果の比較

\section{参考文献}

1) Tsujimoto, T. and S. Murakami: Effect of Transpiration Velocity on Incipient Motion of Bed Materials Particles Resting on Permeable Bed., Memoirs of the Faculty of Technology, Kanazawa University, Vol. 19, No. 2, 1986.

2）中川博次 - 辻本哲郎・中野晋：混合砂れき床の粗度と粒径別移動限界，第 25 回水理講演会論文集， pp. $67 \sim 72,1981$.

3）中川博次・辻本哲郎・村上正吾 : 渓床堆積物の初期移動。一吸い込み・吹き出し速度の粒径別移動限界 への影響一，第 30 回水理講演会論文集, pp. $241 \sim 246,1986$.

4）芦田和男・道上正䂓：移動床流れの抵抗と掃流砂量に関する基礎的研究，土木学会論文報告集， 第 206 号, pp. $59 \sim 69,1972$.

5）中川博次・村上正吾・清水義彦・香西稔：流出入流速の step length に及ぼす影響について，土木学会 第 42 回年次学術講演会講演概要集, II-138, pp. 306 307, 1987.

6）中川博次・辻本哲郎 - 原稔明 : 混合砂れき床面の粗粒化過程について, 京都大学防災研究所年報, 第 20 号 B - 2, pp. $355 \sim 370,1977$. 